LIAMES 15(1): 17-46 - Campinas, Jan./Jun. - 2015

\author{
Fernando O. de Carvalho \\ (Universidade Federal do Rio de Janeiro) \\ Gean N. Damulakis \\ (Universidade Federal do Rio de Janeiro)
}

\title{
The structure of Akroá and Xakriabá and their relation to Xavante and Xerente: A contribution to the historical linguistics of the Jê languages
}

\begin{abstract}
The goal of this paper is twofold: on the one hand, we aim at clarifying aspects of the phonology and morphology of Akroá and Xakriabá, to the extent that these are discernible on the basis of both the interpretation of XIX century vocabulary lists collected by explorers and the comparison with their closest extant relatives, the Xavante and Xerente languages. On the other hand, we show that, by means of this comparison, our knowledge of the nature of the relations among these four languages is greatly advanced, contributing in this way to the historical investigation of the Jê languages at large.
\end{abstract}

KEYWORDS: Akroá; Xakriabá; Akwen; Historical Linguistics.

RESUMO: O presente estudo tem um objetivo duplo: por um lado, buscamos estabelecer aspectos da fonologia e da morfologia das línguas Akroá e Xakriabá, na medida em que essa informação possa ser extraída da análise de listas vocabulares coletadas por viajantes no século XIX e, principalmente, pela comparação desses dados com aqueles disponíveis para o Xavante e o Xerente. Por outro lado, mostramos que, com a comparação dessas quatro línguas, que juntas formam o ramo central da família linguística Jê, o conhecimento sobre esse grupo de línguas pode ser sensivelmente aprofundado.

PALAVRAS-CHAVE: Akroá; Xakriabá; Akwen; Historical Linguistics.

\section{Introduction}

The central branch of the Jê linguistic family (see map below), usually seen as including the Akroá, Xakriabá, Xavante and Xerente languages ${ }^{1}$ (cf. Rodrigues 1999, 2002; Ribeiro \& van der Voort 2010: 549) remains to this day defined mostly on geographical grounds,

\footnotetext{
${ }^{1}$ The single dissenting voice we know of on this regard is Apolinário (2005), who claims that the Akroá would be part of the Timbira group. It should be noted, however, that von den Steinen (1886) also included Maxacalí, along with Xavante, Xerente, Xakriabá and Akroá, within his 'Central Jê' group (cf. Rodrigues 2002). Rodrigues 2002 also notes that Paul Ehrenreich (in 1891) and Wilhelm Schmidt (in 1926) both placed the Jeikó language as being particularly close to Akroá or to both Akroá and the Akwen group (Xavante and Xerente) plus Xakriabá.
} 
still lacking in arguments that would validate it in terms of the usual demands set by a strict application of the comparative method, that is, the identification of uniquely shared innovations in phonology, lexicon and grammar. Indeed, Rodrigues (2002) sets as one of the most urgent tasks for comparative Jê linguistics that of developing lexical comparisons internal to each of its postulated subgroups, with the ultimate goal of reconstructing the proto-languages for each such intermediate set of related languages.

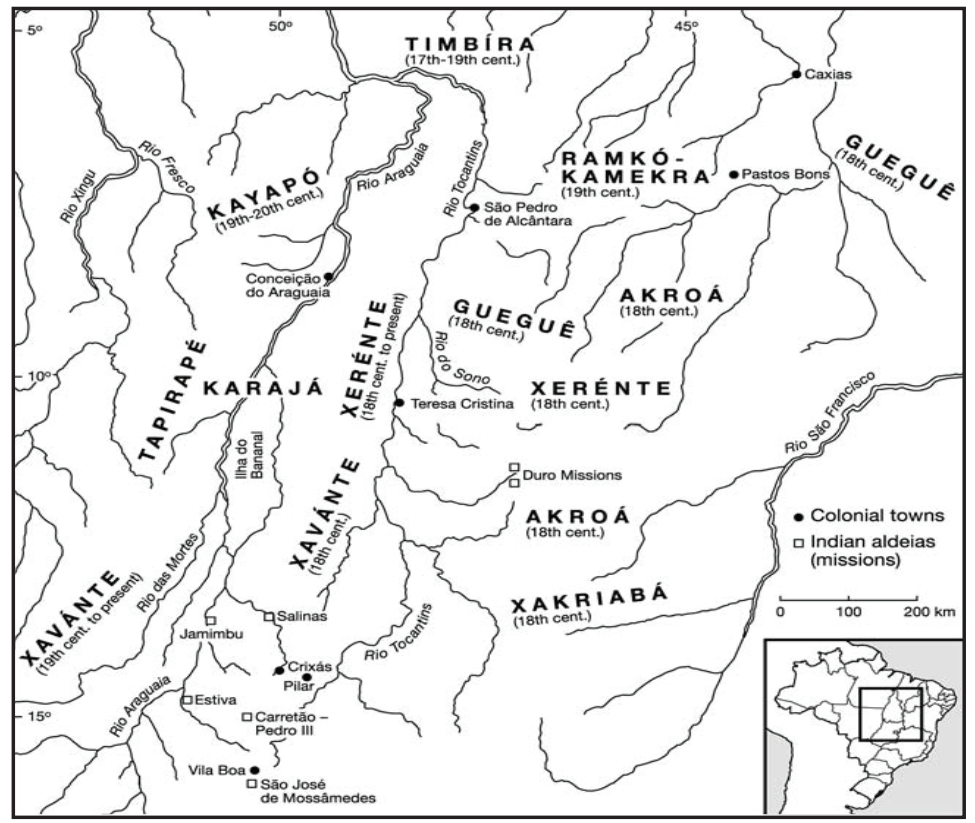

Figure 1: Historical location of Jê groups in the Tocantins-Araguaia region (from Coimbra et al. 2002: 50)

A complicating factor in this venture is, no doubt, the limited documentation available for Akroá and Xakriabá, two of the languages making this group. These are taken to be extinct and all the available information on them exists in the form of a few vocabulary lists: Eschwege (1830), Saint Hilaire (1848), Martius (1867), and, to a lesser extent, in Nimuendajú (n.d.). The limited information available on these languages has in turn contributed to the existence of doubts concerning their relation to the 'Akwen languages', that is, to Xavante and Xerente. ${ }^{2}$ Motivated by this, the present work has as its goal that of uncovering as much information as possible on the phonological and morphological structure of the Akroá and Xakriabá languages, while at the same time contributing to the increase in our knowledge of the historical relations between the languages of the central branch of the Jê family.

\footnotetext{
${ }^{2}$ We will follow authors such as Maybury-Lewis (1967: 2) here and reserve the term 'Akwen' for Xavante and Xerente. This use differs from that of Lowie (1946: 478), for instance, who includes Xakriabá along with Xavante and Xerente in his 'Akwen' section of the central Jê branch, separate from the Akroá section. This is to be understood, however, as a term adopted out of convenience, since, as shown in this paper, there is no strong strictly linguistic evidence in favor of recognizing a subgroup formed by the Xavante and Xerente languages that excludes Akroá and Xakriabá.
} 
This paper is organized as follows: section $\mathbf{1 . 1}$ presents the sources for this study, in particular, the sources of the Akroá and Xakriabá data. Section $\mathbf{1 . 2}$ deals in a brief and general manner with some matters related to the quality and interpretability of these sources. Section 2 provides an overview of the phonologies of the best described central Jê languages, Xavante and Xerente. The original contribution of the paper starts at section 3, devoted to an evaluation of aspects of the phonology of Xakriabá and Akroá to the extent that these relate to two known isoglosses within the central Jê group. All the available etymologies for which a Xakriabá and/or an Akroá word can be matched with their Akwen cognate are amassed in section 4, including a discussion of important points and an incipient morphological analysis of the material from the fragmentary languages. ${ }^{3}$ Finally, section 5 brings up a few more issues on morphological structure. Section 6 ends the paper with a synthesis and conclusion.

\subsection{The sources for the present study}

The entire evidence we have on the Akroá language amounts to a vocabulary list published in Martius $\left(1867\right.$; v.2) under the title of Acroa Mirim. ${ }^{4}$ An additional set of two word forms is found in Gardner (1848). The relevance of the latter was addressed in Ribeiro (2012). In the first volume of his work, at page 281, Martius offers a short discussion of characteristics of this group, such as geographic location and a tentative discussion on the classification of the language. In his view, the Akroá people seems to constitute "an intermediate member between the Jê [Xavante, Xerente, Xakriabá, Kayapó, Jeikó and Massakará] and other groups of the same nation among which they live". ${ }^{5}$ In the absence of indications to the contrary, we assume here that the Akroá data has been gathered by Martius and Spix. ${ }^{6}$

An unpublished comparative list elaborated by the German ethnologist Curt Nimuendajú was also consulted. ${ }^{7}$ This work consists in a German-glossed list of comparative vocabulary from Akroá, Timbira and Akwen languages. Nimuendajú's intent in producing this comparative list was probably that of evaluating Martius' (1867) claim that the language of the Akroá would be closer to that of the Timbira. An inspection of the data shows that the Akroá forms in Nimuendajú come from Martius (1867).

3 'Fragmentary' is an adjective often found in Indo-European studies when referring to languages like Thracian or Messapic on which scant evidence is available. We use this term here with the same broad meaning when discussing Akroá and Xakriabá.

${ }^{4}$ Martius (1867: 281, Vol.1) lists the following names for this group: “Acroás, Aruás, Acruazes, Acrayás”.

${ }^{5}$ On matters related to their location and demography, Martius notes that the closest neighbors to the Akroá are the Xerente, to the southwest, and the Timbira, to the north. He notes further that a population of approximately 1.000 individuals was residing in three villages (Duro, Formiga and São José de Mossamedes) around 1730. According to the author, when Gardner visited these villages he found only 40 Akroá in each of the two largest settlements, while Martius and Spix counted very few individuals in an earlier (1819) visit to São Gonçalo do Amarante.

${ }^{6}$ All the vocabulary lists in Martius (1867) appear with clear indication whenever the vocabularies in question were not gathered by Martius himself. No such indications are found in the Akroá data.

${ }^{7}$ This item belongs into the Nimuendajú archive of the CELIN/Museu Nacional. We are grateful to Lourdes Cristina Araújo Coimbra for all the support in dealing with the material. 
In the comparative list of Nimuendajú (n.d.) some 90 items are presented, with those perceived as cognates appearing with underlining. Of these, 8 are indicated as AkroáTimbira cognates, while more than half of the total appears marked as Akroá-Akwen cognates. The notation indicates, therefore, that Nimuendajú may have arrived at the conclusion that Akroá was closer to Akwen than it was to Timbira, a classification that is, in effect, explicitly advanced in Nimuendajú \& Lowie (1937).

As for the Xakriabá data, Martius (1867) presents a vocabulary list, under the name Chicriabás, which consists in a compilation of lists gathered independently by Ludwig von Eschwege ( published in 1830 as part of his work Brasilien die neue Welt) and Auguste de Saint-Hilaire (published in 1848 in his Voyage aux Source du Rio S. Francisco ). Items taken from the latter source are given in Martius (1867) with a ' $H$ '.

Saint-Hilaire's Xakriabá list, though short (it contains only 39 items), is presented along with useful commentaries on pronunciation and transcription. Having read Eschwege (1830), Saint-Hilaire offers a few remarks on differences between his own Xakriabá notes and those produced by the German pioneer, discussing apparent cases in which aspects of the latter's native language interfered with his transcriptions. Saint-Hilaire notes, for instance, that Eschwege employs $<\mathbf{s c h}>$, which, one assumes, was employed with the value it has in German (i.e. [J]) to render a Xakriabá sound that is actually [3]. The reason for this confusion is, according to Saint-Hilaire, the fact that German lacks a voiced fricative [3]. ${ }^{8}$ Finally, we should mention that both Saint-Hilaire and Eschwege gathered their data from the same speaker, meaning that all the available Xakriabá data comes the idiolect of a single individual. ${ }^{9}$

As noted in section 2 below, the data from the two better described languages - Xavante and Xerente - come mainly from contemporary sources, especially theses and dissertations concerned with phonological and morphological description. On occasion, however, older materials were consulted, in particular whenever the relevant lexical evidence was not available in the more recent sources or whenever the earliest documented forms of these languages was at issue. These materials consist in the Xavante and Xerente lists given in Martius (1867), the Xavante forms in Ehrenreich (1895) and the Xerente vocabulary given in Nimuendaju (1929). The Xavante data in Martius (1867) come ultimately from Castelnau and, to a lesser extent, from Pohl (cf. Pohl 1832). All Xerente forms in Martius (1867) are due to Castelnau alone. ${ }^{10}$ Table in 1 below closes the section, offering a summary of the sources consulted for each language:

${ }^{8}$ In effect, German words in which the fricative [3] occur are usually French loanwords. Saint-Hilaire claims as well that Eschwege would have introduced markings indicating that some prefixal elements could be articles (cf. e.g. the word for 'head' given as $<$ d'aigran $>$ 'Kopf' in Eschwege and $<$ dacran $>$ 'tête' in SaintHilaire).

${ }^{9}$ The old lady in question, when first approached by Saint-Hilaire, denied having any knowledge of the language. The French then told her it was hard to believe that someone could forget a language in two years, given that two years before she was interviewed by Eschwege.

${ }^{10}$ Martius (1867) includes asterisks '*' in all Xerente forms for which he identifies a similar or identical form in Xavante ("Die mit * bezeichneten Wörter gehören auch dem Dialekte der Chavantes an"). 
(1) Sources for the present study:

\begin{tabular}{cc}
\hline Language & Source \\
\hline Xakriabá (Chicriabás) & Eschwege (1830) \\
Saint-Hilaire (1848) \\
Akroá (Acroá-Mirim) & Martius (1867) \\
Xerente (Cherentes, šerente) & $\begin{array}{c}\text { Castelnau (apud Martius 1867); Nimuendajú } \\
(1929), \text { plus sources on the modern language } \\
\text { (cf. section 2) }\end{array}$ \\
Xavante (Chavantes) & Castelnau (apud Martius 1867); Pohl (1832), \\
& Ehrenreich (1895), plus sources on the modern \\
language (cf. section 2)
\end{tabular}

\subsection{Notes on transcription:}

All the data available on Akroá and Xakriabá - as well as part of the material on Xerente and Xavante - consists in its entirety of vocabulary lists transcribed by nonlinguists, employing idiosyncratic and not entirely consistent scripts, which are in addition seldom accompanied by explicit indications of the phonetic values of the symbols used in the transcriptions. We are not going to deal in detail or in an exhaustive manner with the interpretation of these transcriptions, for two reasons. First of all, this is in part a very hard, if not, hopeless task when modern data on the languages in question is not available. Since both Akroá and Xakriabá are extinct languages, no such testimony provided by linguistically-trained individuals is available. The second reason is that only in a limited set of cases is the phonetic interpretation of these transcriptions crucial to the arguments and analyses advanced here. These will be discussed in the body of the text in the following sections whenever the need arises. As shown especially in section $\mathbf{3}$, establishing such correspondences between phonetic values and symbols in transcriptions is either relatively trivial (as in the case of $\langle\mathbf{k}>$ and $\langle\mathbf{c}>$ standing for the velar stop [k]) or very difficult, as in the case of symbols for vowels. For these reasons, we have opted for the inclusion of the Akroá and Xakriabá forms as they appear in the original sources, indicated by angled brackets ' $<>$ '.

Concerning the Akroá data, we note that the transcriptions made by Martius have been independently judged to be lacking in precision and systematicity, especially as the representation of vowels is concerned (Ramirez 2001: 21). In making this evaluation Ramirez (2001) had the benefit of his own descriptions of modern Baniwa do Içana (an Arawak language). For the Xakriabá data we checked the list in Martius (1867) against those given in the original sources, Saint-Hilaire (1848) and Eschwege (1830), looking for any modifications introduced by Martius. Vasconcelos (2009) notes, with respect to Southern Kayapó, that Martius often introduces diacritics not present in the sources of his wordlists. We found no instances in which Martius (1867) has added marks or diacritics to the forms as these appear in Eschwege (1830) and in Saint-Hilaire (1848). 
2. Sources and assumptions on the phonology of the Akwen languages

For Xavante, the following sources of lexical data were consulted: McLeod \& Mitchell (1977); Hall, McLeod \& Mitchell (1987); Santos (2008) and Quintino (2000, 2012). Some observations of linguistic significance were also found in the anthropological monograph of Maybury-Lewis (1967).

We assume the following consonantal inventory for Xavante (after Quintino 2000; 2012):

(2) The Xavante inventory of consonants (after Quintino 2000).

\begin{tabular}{ccccc}
\hline & Labial & Alveolar & Palatal & Glottal \\
\hline \multirow{2}{*}{ Stops } & $\mathrm{p}$ & $\mathrm{t}$ & & $?$ \\
& $\mathrm{~b}$ & $\mathrm{~d}$ & & $\mathrm{~h}$ \\
Fricatives & & $\mathrm{s}$ & & \\
Sonorants & $\mathrm{z}$ & $\mathrm{j}$ & \\
& $\mathrm{w}$ & $\mathrm{c}$ & $\mathrm{j}$
\end{tabular}

An important allophonic process results in the realization of the voiced stops $/ \mathbf{b} \mathbf{d} /$ as [m n] in the context of a following nasal vowel (Quintino 2000: 39-41). On the other hand, as noted in Quintino (2012: 123), it is not the case that all instances of surface nasal stops can be plausibly analyzed as surface variants of underlying oral (voiced) stops. In some instances a nasal stop such as $[\mathbf{m}]$ or $[\mathbf{n}]$ occurs without the presence of a contextual nasal trigger - that is, without a following nasal vowel - and, for that reason, such instances of 'unmotivated' nasal stops will be presented here as nasal phonemes.

The segment presented here as a glottal aspirate /h/ occurs in Quintino (2000) as a voiced velar fricative [ $\mathbf{y}]$. Given, however, its role as a trigger of nasalization, along with additional evidence discussed in Quintino (2012), we opted for deriving all contextual occurrences of [y] from an underlying glottal aspirate /h/ (cf. also Quintino 2012: 83). Many of the forms sampled from Santos (2008) show an affricate [ts] where elsewhere in the literature one finds [s] instead. According to Quintino (2000: 44) [s] and [ts] alternate freely in all contexts and, for this reason, we have normalized all the data taken from Santos (2008) as including phonological $/ \mathbf{s} / .^{11}$

Finally, some comments on the status of the glottal stop/ $/$ in the Xavante phonological system are in order. A number of words in the language are said to be phonologically vowel-initial, though an automatic rule of glottal stop epenthesis is supposed to apply in order to provide these word-initial syllables with onsets (cf. Quintino 2000: 64-5). As a consequence, glottal stops in the context [\#PV] are taken to be surface manifestations of a demand for syllables with an onset, while glottal stops occurring in other contexts are the

${ }^{11}$ Quintino (2000: 39) notes that $/ \mathbf{j} /$ and /z/ alternate in many forms. This morphophonemic alternation seems to serve a morphological purpose, however, being related to the expression of the 'relational morpheme'. See section 5 of the present study. 
realization of a phoneme / $/$ /, thus: /da-?rã/ $\rightarrow$ [da?rã] 'head', but /ə/ $\rightarrow$ [?ə] 'water'. Setting aside the recognition of these two, phonologically distinct glottal stops on synchronic grounds alone, two classes of glottal stops should be recognized for Xavante on comparative-historical grounds. As discussed in section 3 below, we will include, in the Xavante data, all glottal stops that correspond to a velar stop $\mathbf{k}$ in Xerente (even those occurring in word-initial position); glottal stops that appear in Xavante phonetic forms but that lack a corresponding $\mathbf{k}$ in their Xerente cognates are not indicated. Thus, the Xavante word for 'person', given in Quintino (2000: 95) as [?a'?wẽ)], is represented here as /âwẽ)/. The first, word-initial glottal stop is the result of the above-mentioned epenthesis rule, and has no correspondent in the Xerente cognate. The word-internal glottal stop, however, is likely the result of a debuccalization change ${ }^{*} \mathbf{k}>\mathbf{~}$, as shown by the cognate Xerente form [akwẽ]. A case of word-initial glottal stop is the Xavante noun meaning 'water', /Pə/, whose Xerente cognate is /kə/.

The sources consulted for Xerente are Mattos (1973), Krieger \& Krieger (1994), Sousa Filho (2005; 2011) and Souza (2008). The Xerente consonantal inventory is given in Souza (2008):

(3) The Xerente inventory of consonants (after Souza 2008):

\begin{tabular}{cccccc}
\hline & Labial & Alveolar & Palatal & Velar & Glottal \\
\hline Stops & $\mathrm{p}$ & $\mathrm{t}$ & & $\mathrm{k}$ & \\
& $\mathrm{b}$ & $\mathrm{d}$ & & \\
Fricatives & $\mathrm{m}$ & $\mathrm{n}$ & & $\mathrm{h}$ \\
& & $\mathrm{s}$ & & \\
Sonorants & & $\mathrm{z}$ & & \\
& $\mathrm{w}$ & $\mathrm{c}$ & & \\
\hline
\end{tabular}

As noted, Xerente has a velar stop / $\mathbf{k}$ / which is lacking in Xavante. ${ }^{12}$ Souza (2008) also includes two nasal stops $/ \mathbf{m} \mathbf{n} /$ which are absent from the Xavante inventory above. The difference here is superficial, however, due to the observations above implying that, for some lexical items at least, underlying nasal stops may have to be postulated for Xavante.

The inventory of oral vowels is the same for the two languages:

(4) The oral vowel inventory of Xavante and Xerente (after Quintino 2000; Souza 2008):

\begin{tabular}{cccc}
\hline & Front & Central & Back \\
\hline High & $\mathrm{i}$ & $\dot{\mathrm{i}}$ & $\mathrm{u}$ \\
Mid & $\mathrm{e}$ & $\partial$ & $\mathrm{o}$ \\
Low & $\varepsilon$ & $\mathrm{a}$ & 0 \\
\hline
\end{tabular}

${ }^{12}$ Quintino (2012) discusses the limited presence of $\mathbf{k}$ in a few ideophones. 
For the inventory of nasal vowels, Quintino (2000: 49) postulates /ĩ $\tilde{\mathbf{e}} \tilde{\mathbf{v}} \tilde{\mathbf{o}}$ )/ for

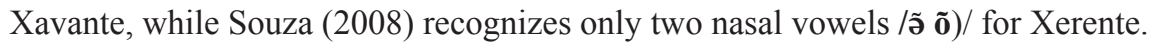

\section{Comparative phonology of Central Jê and its internal structure}

As the reader may have noticed from the discussion in section $\mathbf{1}$, there has been some ambivalence in the proposals concerning the relations between the languages making the central Jê group. Though all researchers agree in classifying Xavante and Xerente as particularly close to each other, forming a cluster known as 'Akwen', there are differing views on the relation between these languages and the other members of the group.

The Akwen cluster (see footnote $\mathbf{2}$ on the status of this entity) forms a natural 'base of comparison' or pivot for assessing the place of the other languages, given their status as the best known languages in the group. Of potential relevance for claims of subgrouping and relative proximity between languages of the central Jê group, we note that the two members of the Akwen cluster are separated from each other by two clear phonological innovations. The first, illustrated by the comparative data in (5) below, is the systematic correspondence between a dorsal stop in Xerente and a glottal stop in Xavante, a pattern of correspondence that may be projected on a diachronic plane by the correspondence *k > ? (Rodrigues 1999: 178):

(5) Correspondence Xerente $\mathbf{k}$ : $\mathbf{1}$ Xavante:

\begin{tabular}{|c|c|c|c|}
\hline (a) & ake & a?e & 'necklace' \\
\hline (b) & kuba & Puba[?re] & 'canoe, boat' \\
\hline (c) & [z]akru & [z]a?ru & 'village' \\
\hline (d) & kupi & Pupi & 'electric fish' \\
\hline (e) & sika & si?a & ‘chicken’ \\
\hline (f) & krawa & Prawa & 'agouti' \\
\hline (g) & wakõ & wa?õ & 'coati' \\
\hline (h) & kukã & Pu?ã & 'turtle' \\
\hline (i) & kupa & Pupa & 'manioc' \\
\hline (j) & kə & ?ә & 'water' \\
\hline (k) & kuzə & Puzə & 'fire' \\
\hline (1) & kra & Pra & 'son’ \\
\hline (m) & pikõ & pî̃õ & ‘woman' \\
\hline (n) & kwa & ?wa & 'tooth' \\
\hline (o) & krã & Prã & 'head' \\
\hline (p) & saku & sa?u & 'to blow' \\
\hline (q) & kupsõ & Pupsõ & 'to wash' \\
\hline (r) & -kwa & $-? w a$ & Agentive suffix \\
\hline
\end{tabular}

The existence of a correspondence $\mathbf{k}: \mathbf{P}$ is in itself enough to suggest a direction of change *k $\mathbf{k}$ ?, via some sort of debuccalization process, rather than the reverse *? $>\mathbf{k}$, which would imply the insertion of velar (or dorsal) place features, as the most natural development. In addition to rather general considerations of phonetic plausibility for 
transitions between diachronic states, three other sets of evidence agree in pointing to a Xavante innovation in this regard. First of all, loanwords show the same process of debuccalization of the velar stop: thus, the Xavante form for 'banana' is pa?o, clearly a Tupi-Guarani loan, from pakoßa (Tupinambá: <pacova>; Ribeiro (2009: 65) and Ehrenreich (1895: 155)) or a similar form (cf. Nordenskiöld 1922: 76 and Ribeiro 2009 who note the presence of the same form in other Macro-Jê groups such as the Bororo, Kipeá and Coroado, in all these cases with the velar stop of the source form preserved as such).

Documentary evidence shows, in addition, that this change is a recent one in the history of the language. Xavante data from the XIX century attests the preservation of the velar stops: ${ }^{13}$

(6) Absence of * $\mathbf{k}>\mathbf{P}$ in earlier attested Xavante forms:

\begin{tabular}{cccc}
\hline Contemporary Xavante & Martius 1867 & Ehrenreich 1895 & \\
\hline Puba?re & $<$ coubacré $>(\mathrm{C})$ & $<\mathrm{k}$-uba $>$ & 'boat, canoe' \\
Pumpirã & $<$ comunica $>(\mathrm{P})$ & $<$ kumikan $>$ & 'bow' \\
?ə & $<$ keu $>(\mathrm{P})$ & $<\mathrm{kō}>$ & 'water' \\
ti?a & $<$ tika $>(\mathrm{P})$ & $<$ tika $>$ & 'earth' \\
pa?o & $<$ baco $>(\mathrm{C})$ & $<$ pako $>$ & 'banana' \\
-?wa & ---------- & $<$ da-kua $>$ & 'tooth' \\
\hline
\end{tabular}

The relatively recent date of this change, as well as that of the other isogloss separating the Xavante and Xerente languages will be addressed more fully below.

Further evidence in favor of the innovative nature of the Xavante state in the correspondence $\mathbf{k}:$ ? comes from a comparison of cognate forms from outside the central Jê branch. A rapid inspection of forms from other Jê groups indicates that $* \mathbf{k}>\mathbf{P}$ in Xavante is much more likely than the change of Proto-Jê *k to *? in Proto-central Jê, just to have these reversed to the etymological $\mathbf{k}$ again in Xerente:

${ }^{13}$ Rodrigues (2004: 117-8) claims that contemporary Xavante is not the direct continuation of the 'Chavante' language whose forms are attested in the lists of Castelnau and Pohl (i.e. those appearing in Martius 1867). Since, in our opinion, Rodrigues' arguments to this effect are not compelling enough to make this a settled issue, we have ignored them in the discussion of the comparisons above. Be as that may, the reader is referred to Rodrigues' thoughtful discussion of the matter, including his observations on the difficulties created by the application of the term 'Xavante' to different peoples in the past (Rodrigues 2004: 119 , note 5).

${ }^{14}$ Ehrenreich's Xavante data was collected 7 years before its appearance in print, that is, in 1888.

${ }^{15}$ The contemporary Xavante form for 'bow' is given here in its phonetic form (with nasal stops) rather than in its underlying form, in order to make comparison with the older documental forms more transparent. Based on Quintino (2000: 86) and in the observations made here in section 2, its phonological form would be /ubjĩ?ã/. 
DE CARVALHO \& DAMUlakis - The Structure of Akró́ and Xakriabá ...

(7) Outgroup comparisons indicating *k $>\mathbf{P}$ in Xavante:

\begin{tabular}{|c|c|c|c|}
\hline Xavante & Xerente & Outgroup & \\
\hline ?ri & kri & $\begin{array}{l}\mathrm{kr} \varepsilon_{\text {Kaingang }} \\
\text { (i)kre }{ }_{\text {Apinajé }}\end{array}$ & 'house' \\
\hline Prã & krã & $\begin{array}{l}\mathrm{kr} \tilde{\Lambda}_{\text {Apinajé }} \\
\mathrm{kr} \tilde{1}_{\text {Kaingang }}\end{array}$ & 'head' \\
\hline ti?a & tka & pika ${ }_{\text {Apinajé }}$ & 'earth' \\
\hline
\end{tabular}

The second correspondence set shows that Xerente was seemingly subject to a process of vowel deletion (or weakening) prompted by a rightward stress shift (see also Mattos 1973; Ribeiro \& van der Voort 2010: 554). ${ }^{16}$

(8) Correspondence Xerente Ø : V Xavante:

$\begin{array}{lllll}\text { (a) -bdu } & : & \text {-budu } & \text { 'neck' } \\ \text { (b) -zdawa } & : & \text {-zadawa } & \text { 'mouth' } \\ \text { (c) -pra } & : & \text {-para } & \text { 'foot' } \\ \text { (d) bdə } & : & \text { bədə } & \text { 'sun' } \\ \text { (e) tka } & : & \text { ti?a } & \text { 'earth' } \\ \text { (f) kne } & : & \text { Pẽne } & \text { 'stone' } \\ \text { (g) arbo } & : & \text { arobo[re] } & \text { 'bat' } \\ \text { (h) tbe } & : & \text { tebe } & \text { 'fish' } \\ \text { (i) kdə } & : & \text { uhədə } & \text { 'tapir' 17 } \\ \text { (j) bru } & : & \text { buru } & \text { 'farm, garden' } \\ \text { (k) wde } & : & \text { wede } & \text { 'tree' }\end{array}$

In comparison to the change * $\mathbf{k}>\mathbf{P}$ in Xavante, in this case, noting whether the change had applied already at the time the older Xerente lists were gathered proves to be much more complicated. The problem lies, of course, in the unsystematic and coarse character of the transcriptions of vowel sounds in these sources. More to the point, however, is the phonological nature of the modern Xerente forms as opposed to the phonetic character of the early vocabulary lists. Items with underlying consonant clusters in Xerente, such as /kne/ 'stone', actually show realizations in which very short 'transition vocoids' (Souza 2008: 79-80) are heard as a function of varying phonetic conditions. For various reasons - their predictable quality, their reduced realization in comparison to bona fide underlying vowels - these weak vocoids are left out of phonological representations. It is not far-fetched to suppose, therefore, that older Xerente transcriptions, being phonetic, would reveal the presence of such vowels, though it is not clear that such phonetically

${ }^{16}$ The fact that in many of these items - especially (a), (b), (d), (f), (h), (j) - the vowel that is lost in Xerente has the same quality as that of the following syllable is related to a process of vowel insertion in word-final position which took place in the history of many Jê languages. This will be discussed in section 5 .

${ }^{17}$ As shown by the form for 'tapir', PJ *k yields $\mathbf{h}$ instead in Xavante in a few cases. In effect, (Davis 1966: 14), $\mathbf{h}$ is the regular outcome preceding $\mathbf{\partial}$. 
reduced transition vocoids are in any sense systematically distinguished from underlying vowels. A comparison of contemporary Xerente forms with those sampled in Martius (1867) and those in the vocabularies of Ehrenreich (1895) and Nimuendajú (1929) reveals the presence of vowels in many words, in contexts where only transition vocoids are found in the modern language:

(9) Contemporary Xerente forms compared with earlier attested forms:

\begin{tabular}{ccccc}
\hline $\begin{array}{c}\text { Contemporary } \\
\text { Xerente }\end{array}$ & $\begin{array}{c}\text { Castelnau (apud } \\
\text { Martius 1867) }\end{array}$ & $\begin{array}{c}\text { Ehrenreich } \\
\mathbf{( 1 8 9 5 )}\end{array}$ & $\begin{array}{c}\text { Nimuendajú } \\
\text { (1929) }\end{array}$ & \\
\hline kne & $<$ kanai $>$ & $<$ kinä $>$ & $<$ kẹ̆në $>$ & 'stone' \\
bdə & $<$ beudeu $>$ & $<$ bẹdụ, budù $>$ & $<$ bubị $>$ & 'sun' \\
arbo & $<$ arbo $>$ & -------- & -------- & 'bat' \\
tka & $(<$ choupra $>)$ & $(<$ sūpa $>)$ & $<$ tka $>$ & 'earth' \\
wde & $(<$ couba $>)$ & $<$ udeä $>$ & $<$ wude $>$ & 'tree' \\
kdə & $<$ coudieu $>$ & $<$ kuduo $>$ & $<$ kẹdị $>$ & 'tapir' \\
\hline
\end{tabular}

For simplicity sake we assume here that both changes - *k $>\mathbf{P}$ in Xavante and $* \mathbf{V}>\boldsymbol{\varnothing}$ in Xerente - came to completion when the two Akwen groups split. We follow Maybury-Lewis (1965: 351; 1967: 2) and Coimbra et al. (2002: 29, 68-9) and take the date of this split to start at 1850. Maybury-Lewis (1965: 351), for instance, states that from a comparison of the lexical material in Martius (1867) it is "not possible to say that the two tribes were linguistically discrete at the beginning of the nineteenth century". By 1860 it is believed that the geographic separation between the Xavante and the Xerente groups was complete, given the fact that some ten years before large Xavante settlements were reported west of the Araguaia (Coimbra et al. 2002). It is not surprising, therefore, that the data in Nimuendajú (1929) reveal forms such as $<$ tka $>$ and $<$ kẹ̆në $>$ which seem to show the effect of vowel loss or reduction (note the brevis diacritic in the first vowel of 'stone'). Some of the forms in Ehrenreich ('stone', 'sun', 'tapir') and Martius ('bat'; cf. Xavante/arobore/ with the same meaning) suggest the same, but are harder to interpret.

Since our focus here lies in the other two central Jê languages, Xakriabá and Akroá, we may set aside for now the issues concerning the correct dating of the sound changes underlying the correspondence patterns above (though we will come back to it at the end of this section). The crucial question here is: are any of the innovations inferred from the Xavante and Xerente data in (5) and (8) shared with either of the two other languages?

The relatively recent date of the change in Xavante is consistent with the fact that both Xakriabá and Akroá do not share this change and preserve instead all the inherited dorsal stops (in $\mathbf{1 0}$ and $\mathbf{1 1}$ the roots in the Xakriabá and Akroá words are indicated in bold. Morphological analysis will be discussed in greater detail in sections $\mathbf{4}$ and 5): 
DE CARVALHO \& DAMULAKIS - The Structure of Akró́ and Xakriabá ...

(10) Data showing the presence of a dorsal stop in the Akroá and Xakriabá data:

\begin{tabular}{|c|c|c|c|c|}
\hline Xavante & Xerente & Xakriabá & Akroá & \\
\hline -?rã & -krã & $<$ dacran $>,<$ d'agrang $>$ & <aicrán> & 'head' \\
\hline$-? w a$ & $-\mathrm{kwa}$ & & <aiquá> & 'tooth \\
\hline -ib?rada & -ipkra & $<$ dajipcra $>,<$ d'aschipigrá $>$ & <assubckrá> & 'hand' \\
\hline pi?õ & pikõ & $<$ picon $>$ & & 'woman' \\
\hline$-?$ ra & $-\mathrm{kra}$ & <ingrá > & <ingcrá> & 'son’ \\
\hline si?a & sika & <schiká> & $<$ sica $>$ & 'chicken' \\
\hline uhədə & kdə & $<$ cutó $>$ & & 'tapir' \\
\hline ?ri & kri & $<$ gri $>$ & $<\mathbf{k l i}>$ & 'house' \\
\hline ?upa & kupa & & <cuipá> & 'manioc' \\
\hline tipa & tka & $<$ tica $>$ & $<$ tickáiti $>$ & 'earth’ \\
\hline ?ə & $\mathrm{kə}$ & $<\mathbf{k u}, \mathbf{k} \ddot{\mathbf{u}}>$ & & 'water' \\
\hline Puzə & kuzə & $<$ kutsché $>$ & $<$ kutschiopdé(i) $>$ & 'fire' \\
\hline
\end{tabular}

The identification of the velar stops in the Xakriabá and Akorá data depends, of course, on the (seemingly unproblematic) assumption that $<\mathbf{c}>,<\mathbf{k}>,<\mathbf{c k}>,\langle\mathbf{g}>$ correspond to $/ \mathbf{k} /$ in the forms above. Acceptance of this interpretation is warranted given published evaluations of the transcription conventions employed not only by Auguste de Saint-Hilaire but also by German travelers such as Pohl (cf. e.g. Vasconcelos 2009). Since the preservation of the velar stops in Akroá, Xakriabá and Xerente constitutes a shared retention, it cannot be used as argument for placing these three languages as a cluster or subgroup within the central Jê subgroup.

Regarding the correspondence in (8), however, the scenario is not as clear. Below we present those forms from the Xakriabá and Akroá lists that might indicate the presence of vowel reduction and the consequent formation of consonant clusters, as observed in modern Xerente:

(11) Data showing apparent cases of vowel reduction/loss in Akroá and Xakriabá:

\begin{tabular}{|c|c|c|c|c|}
\hline Xavante & Xerente & Xakriabá & Akroá & \\
\hline tîa & tka & $<$ tica $>$ & $<$ tickáiti> & 'earth' \\
\hline $\mathrm{pu}$ & pku & & <puckúte> & 'lake' \\
\hline tebe & tbe & $<$ tupe $>$ & & 'fish' \\
\hline uhədə & $\mathrm{kd}$ & $<$ cutó $>$ & & 'tapir' \\
\hline -para & -рra & $<$ daprá $>$, d' aprá & & 'foot' \\
\hline
\end{tabular}




\begin{tabular}{ccccc}
\hline -budu & -bdu & $<$ d' aputú $>$ & <aimbuttúde & 'neck' \\
-maparane & $($ ponkwa'ne $)$ & $<$ prané $>$ & & 'two' \\
-irada & $<$ ikrda $>$ & $<$ angrata $>$ & $<$ ingerata $>$ & 'grandfather' \\
ropese & psere & $<$ dapside $>$ & $<$ aimbösetí> & 'good, beautiful' \\
-zadawa & -zdawa & & $<$ assötauá $>$ & 'mouth' \\
wede & wde & & $<$ uöthésu & 'tree' \\
\hline
\end{tabular}

Forms like $<$ dapside $>$, $<$ daprá $>$, $<$ prané $>$ seem to indicate quite clearly that vowel reduction was also operative in Xakriabá. The same could be possibly said of forms such as $<$ tupe $>$ and $<$ cutó $>$, assuming $<\mathbf{u}>$ to stand for the predictable transitional vocoid appearing between two phonologically adjacent consonants. Such transitional elements are often 'colored' by the place of articulation features of neighboring elements and the fact that it appears as $<\mathbf{u}>$ in the context of grave consonants $<\mathbf{p}>$ [p] and $\langle\mathbf{c}>[\mathbf{k}]$ would come as no surprise. Indeed, Souza (2008: 80) notes that a transition vocoid of a quality that approximates that of $[\mathbf{u}]$ occurs in the context of labial and velar stops in Xerente (e.g. /pku/ 'lake' [p'k ku]). For a form such as $<\mathbf{d}$ 'aputu $>$ a similar inference cannot be made, since $<\mathbf{u}>[\mathbf{u}]$ is also the phonetic value of the etymological vowel as preserved in Xavante (the same observation applies for the Akroá words for 'lake' and 'neck').

For the Akroá form < aimbösetí> it might as well be argued, based on systematic correspondences between the Akroá transcriptions and the data from modern Akwen languages, that vowel reduction had occurred. ${ }^{18}$ There seems to be independent evidence that Martius' $<\ddot{\boldsymbol{o}}>$ stands for a schwa [ə] or a similar weak vowel often heard between members of consonant clusters. Thus, to the Akwen form for 'maize', /dõzo/, one finds the corresponding Akroá item $<$ notschiö $>$, suggesting a value [ə] for $<\ddot{\boldsymbol{0}}>$. The same symbol $<\ddot{\mathbf{o}}>$ occurs in Akroá where one finds a consonant cluster in Xerente, as in the form for 'mouth' above. Finally, the form for 'leaf' in Akroá seems to include the root for 'tree' followed by a root (or classifier?) for 'leaf' properly: <uöthésu> (cf. Xavante /-su/ 'leaf'). The form for 'tree' is /wede/ in Xavante, but /wde/ in Xerente (cf. Mattos 1973: 1), with the cluster /wd/ arising from the process of vowel loss. We expect then that, in Xerente, the phonetic realization of /wde/ may include, among a range of realizations, forms such

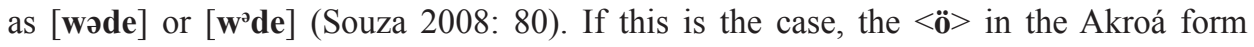
would, once more, correspond to a reduced vocoid in Akwen. There is, in sum, some sizeable amount of evidence suggesting that $<\ddot{\mathbf{0}}>$ in Martius' Akroá forms corresponds to a schwa-like vowel and that, therefore, the process of vowel reduction was in course in the language at the time these lists were produced.

\footnotetext{
${ }^{18}$ Another occurrence of this same basic root is found in Gardner (1848). As discussed in Ribeiro (2012), the Akroá form ropechedy, meaning 'beautiful place', has a clear Central Jê etymology. This form can be reduced to ropeche-, meaning 'beautiful, good', and is identical to its Xavante cognate, is indicated in Ribeiro (2012) and in (11) above. The form is also clearly related to the one given in Martius. See section 5 for some issues in the morphological parsing of the Akroá and Xakriabá data.
} 
What are the implications of these comparative observations? As noted, the preservation of $\mathbf{k}$ in Akroá and Xakriabá shows only that Xavante is alone among central Jê languages in being subject to * $\mathbf{k}>\mathbf{2}$, not allowing any inferences concerning subgrouping. The apparent cases of vowel reduction or complete deletion in Akroá and Xakriabá are more complex, mainly due to the above-mentioned uncertainties in the interpretation of the testimony on these two languages. If these are accepted as showing that vowel reduction had occurred in the 'fragmentary languages' as well, this could, in principle, be seen as evidence for a subgroup having Xerente, Akroá and Xakriabá, with Xavante as a separate branch within central Jê. For some this solution might seem counterintuitive, due to the assumed existence of an 'Akwen subgroup' within central Jê that would include Xerente and Xavante. There is, in effect, little in the way of strictly linguistic evidence for the existence of such a subgroup, that is, innovations in phonology, morphology and syntax shared by Xavante and Xerente only, to the exclusion of Akroá and Xakriabá. Two alternative hypotheses come to mind: in a 'diffusion scenario', the vowel reduction change would have affected Xerente and then diffused, along with lexical borrowing, to its southern neighbors Akroá and Xakriabá. Since the speech varieties in question are extremely close to each other, the occurrence of borrowing in this case would be hard to detect. A different account would postulate an alternation between reduced and unreduced forms (say, [kene] $\sim[$ kəne $] \sim\left[\mathbf{k}^{2} \mathbf{n e}\right] \sim[\mathbf{k n e}]$ ) to a "proto-central Jê dialect chain", with the reduced forms being generalized in Xerente, Xakriabá and Akroá, independently, after this dialect continuum was broken. It is beyond our goals here to decide which of these hypotheses fits best the attested comparative data. Still, we are confident that merely posing these questions based on the analyses presented in this section constitutes, in itself, an advance, even though a complete picture of the diversification of the central Jê languages will probably remain beyond reach, due to the extremely fragmentary data on the already extinct Akroá and Xakriabá languages.

\section{Central Jê etymologies and a tentative morphological analysis}

In this section we present all the etymologies for which a form found in at least one of the 'fragmentary' languages could be matched with their cognates in Xavante and Xerente. Some of the etymologies are discussed in greater detail, due to non-obvious analytical issues and hypotheses suggested by the comparison or when some interesting inferences concerning the history of the Central Jê peoples can be hinted at. Particular importance is attached to morphological analyses of the Akroá and Xakriabá forms. In some cases, prima facie or obvious cognate forms from other branches of the Jê family are included for comparison, as well as their likely Proto-Jê antecedents (from Davis 1966). The etymologies also include forms reconstructed for the Proto-Central Jê language. Due to the shallow depth of this subgroup and the relatively well-understood nature of the phonological differences between Xavante and Xerente (discussed in section $\mathbf{3}$ above), most of these reconstructions are rather obvious and uncontroversial, though their postulation is a necessary first step for future work aimed at probing more seriously on the status of central Jê vis-à-vis the other subgroups of the Jê family. 
The Xakriabá forms followed by (E) come from Eschwege; those followed by $(\mathrm{H})$, from Saint-Hilaire.

HEAD:

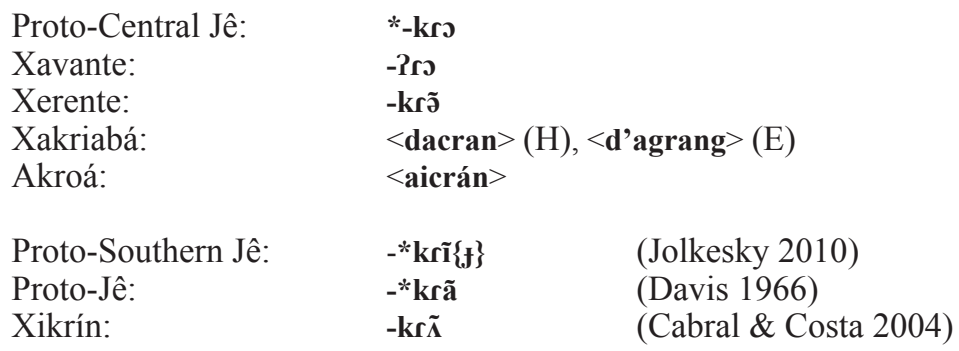

Many Xakriabá words, in the etymology above and in many of the other etymologies below, include the prefix $<\mathbf{d a}$ - $>$ that indicates generalized human possession, a marker that occurs with inalienable nouns whenever they lack a specific possessor. This prefix has the form /da-/ in both Xavante and Xerente. In Akroá, the 2SG prefix $<\mathbf{a i}->$ is equally prevalent. ${ }^{19}$ The cognate prefix in Xavante and Xerente is respectively /aj-/ (McLeod \& Mitchell 1977: 48; Santos 2008) and /ai-/ (Sousa Filho 2011: 116). On the variant $<\mathbf{d}$ 'a-> appearing in Eschwege's transcriptions, see footnote 8.

EYE:

$\begin{array}{ll}\text { Proto-Central Jê: } & *-\text { to } \\ \text { Xavante: } & -\mathbf{t o} \\ \text { Xerente: } & \text {-to } \\ \text { Xakriabá: } & <\text { datoman }>(\mathrm{H}) \\ \text { Akroá: } & <\text { ainthó }> \\ & \\ \text { Proto-Jê: } & *-\mathbf{n o} \\ \text { Timbira Apãniekrá: } & \mathbf{- t o}\end{array}$

We were unable to identify, in either Xavante or Xerente, a formative cognate with the formative <-man> that seems to follow the root for 'eye' in Xakriabá. As in the entry for HEAD above, the prefixes for 'generalized human possession' $<$ da- $>$ and second person singular $<\mathbf{a i}->$ occur in the Xakriabá and Akroá forms, respectively.

EAR:

$\begin{array}{ll}\text { Proto-Central Jê: } & \text { *-po-kre } \\ \text { Xavante: } & \text {-po?re } \\ \text { Xerente: } & \text {-pokre } \\ \text { Xakriabá: } & <\text { daïpocri> (E) } \\ \text { Akroá: } & <\text { aspocklü> }\end{array}$

${ }^{19}$ The elicitation context for this form is familiar to fieldworkers. The native speaker was probably asked about his "word for head" by a researcher placing a hand in his own head, thus prompting the speaker to say "your (sg.) head". A striking confirmation of this is provided by the form for VAGINA, which appears instead with the prefix for generalized human possession. 
Nose:

Proto-Central Jê: *-nisi-kre

Xavante: $\quad$-nsi?re

Xerente: $\quad$-nkre

Xakriabá: $\quad<$ dascri $>(\mathrm{H}),<$ d'asigrí $>(\mathrm{E})$

Xakriabá form occurs with the generalized human possession prefix $<$ da- $>$.

Mouth:

$\begin{array}{lll}\text { Xavante: } & \text {-zadawa } \\ \text { Xerente: } & \text {-sdawa, -zdawa }{ }^{20} & \\ \text { Xakriabá: } & <\text { daïdaua }>(\mathrm{H}) & \\ \text { Akroá: } & <\text { assötauá> } \\ & & \\ \text { Proto-Jê: } & \text { *za-zkwa } & \text { (Davis 1966) }\end{array}$

In the Xakriabá and Akroá words one finds once more the prefix $<\mathbf{d a}->$ and $<\mathbf{a}->$, respectively.

TONGUE:

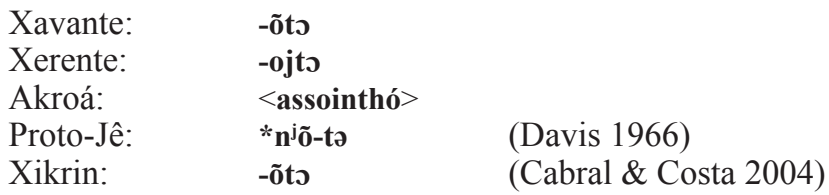

Akroá form includes 2 sg prefix $<\mathbf{a}->$.

Тоотн:

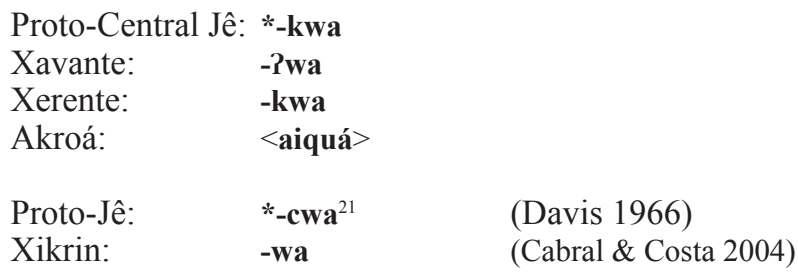

The 2 sg prefix $<\mathbf{a i}->$ is found in the Akroá form.

NeCK:

$\begin{array}{ll}\text { Proto-Central Jê: } & \text { *-budu } \\ \text { Xavante: } & \text {-'budu } \\ \text { Xerente: } & \text {-bdu }\end{array}$

${ }^{20}$ In the Xerente word for 'mouth', note that the initial fricative may be a 'relational morpheme', according to Sousa Filho (2011: 117) who gives the form /ai-s-dawa/ 'your (sg.) mouth'. These and other sources on modern Akwen languages are not consistent on this matter, though. Ribeiro (2004: 94) also indicates the inclusion of the relational morpheme in Davis' (1966) proto-Jê form for 'mouth'. See section 5.

${ }^{21}$ According to Ribeiro (2004) the form * cwa reconstructed by Davis (1966) includes a relational morpheme. The root for 'tooth' would be actually *-wa or *-ua (cf. Ribeiro \& van der Voort 2010: 558). 


$\begin{array}{lc}\text { Xakriabá: } & \begin{array}{l}<\text { d'aputû }>(\mathrm{E}) \\ \text { Akroá: }\end{array} \\ & <\text { aimbuttúde }> \\ \text { Proto-Je: } & \quad \text { *-mut } \\ \text { Timbira Apãniekrá: } & \text {-put }\end{array}$

(Davis 1966)

(Alves 2007)

The Akroa form seems to include the 'copula' or 'predicator' $<-$ de $>$ and probably means "(it) is your neck". In Xavante the form is / $\mathbf{d i}$ / and is variously described as a 'copula' or as a 'predicator'.

CHest:

$\begin{array}{ll}\text { Proto-Central Jê: } & \text { *-õkudu } \\ \text { Xavante: } & \text {-õ?udu } \\ \text { Xerente: } & \text {-õknõ } \\ \text { Xakriabá: } & <\text { d'anhocutû> }>(E) \\ \text { Akroá: } & <\text { assockthúdü> }\end{array}$

The Proto-Central Jê form is rather tentative in this case. No doubt a more precise reconstruction would issue from a more thorough understanding of nasalization in Xavante and Xerente. Thus, a form - $\mathbf{0}$ kdo could be postulated instead for Xerente if the nasal feature of the consonant in this case could be factored out as the predictable contextual effect triggered by the nasal vowel. The mismatches in vowel quality and in the extent of vowel nasalization are also hard to explain at this point.

ARM:

$\begin{array}{ll}\text { Proto-Central Jê: } & \text { *-pa } \\ \text { Xavante: } & \text {-pano } \\ \text { Xerente: } & <\text { da pakrdã> } \\ \text { Xakriabá: } & <\text { dapá> }(\mathrm{E}) \\ \text { Akroá: } & <\text { aipáckü> }\end{array}$

Proto-Jê: *pa (Davis 1966)

HAND:

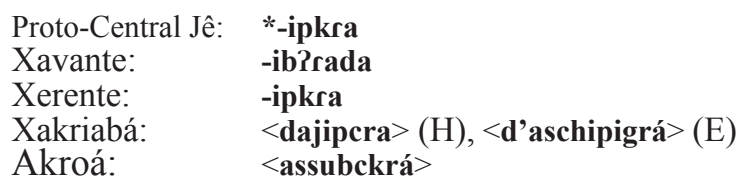

Proto-Jê: *-jĩ-kra (Davis 1966)

The symbol $<\mathbf{j}>$ in Saint-Hilaire corresponds to [3] (Vasconcelos 2009: 417) thus agreeing in place (palatal) with the consonant in Xavante (cf. comments in section $\mathbf{1}$ above).

LEG:

$\begin{array}{lll}\text { Proto-Central Jê: } & * \text {-te } & \\ \text { Xavante: } & \text {-te } & \\ \text { Xerente: } & \text {-te } & \\ \text { Akroá: } & \text { <aithé> } & \\ & & \\ \text { Proto-Jê: } & *-t \varepsilon & \text { (Davis 1966) }\end{array}$ 
Note prefix $<\mathbf{a i}->$ in Akroá.

Fоот:

Proto-Central Jê:

Xavante:

Xerente:

Xakriabá:

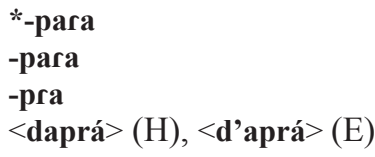

Proto-Jê: *-par

(Davis 1966)

Timbira Apâniekrá: $\quad$-par

(Alves 2007)

BLOOD:

Proto-Central Jê:

*-wa-pru

Xavante:

-'wapru

Xerente:

-wa'pru

Akroá:

$<$ tauabrú $>$

Proto-Jê:

*-ka-mro

(Davis 1966)

The Akroá form seems to contain the prefix for generalized human possession $<$ ta- $>$.

BONE:

Proto-Central Jê:

$$
\begin{aligned}
& \text { *-hi } \\
& \text {-hi } \\
& \text {-hi } \\
& <\text { thahické> }
\end{aligned}
$$

Xavante:

Xerente:

Akroá:

Proto-Jê:

*-zi

Xikrin:

Suyá:

-i

$-\mathbf{s i}$

The Akroá form seems to contain the prefix for generalized human possession, here given as $<$ tha- $>$.

VAGINA:

$\begin{array}{ll}\text { Proto-Central Jê: } & \text { *-kre } \\ \text { Xavante: } & \text {-?re } \\ \text { Xerente: } & \text {-kre } \\ \text { Xakriabá: } & <\text { d'agri }>(\mathrm{E}) \\ \text { Akroá: } & <\text { tacklï }>\end{array}$

In this case, both Xakriabá and Akroá show the prefix for general human possession, $<\mathbf{d}$ 'a- $>$ and $<$ ta- $>$.

GRANDFATHER:

Proto-Central Jê: $\quad$ *-krada

Xavante:

-Prada

Xerente:

Xakriabá:

$<$ ikrda $>$

Akroá:

$<$ angrata $>(\mathrm{E})$

$<$ ingerata $>$ 
WOMAN:

ProtoCentral Jê: *pikñ

Xavante: pi?õ

Xerente: pikñ

Xakriabá: $\quad<$ picon $>(\mathrm{H})$

SoN:

$\begin{array}{ll}\text { Proto-Central Jê: } & \text { *-kra } \\ \text { Xavante: } & \text {-?ra } \\ \text { Xerente: } & \text {-kra } \\ \text { Xakriabá: } & <\text { ingrá> }>(E) \\ \text { Akroá: } & <\text { ingcra }>\end{array}$

CHILD/BABY:

Proto-Central Jê: *aikute

Xavante: ai?uté (baby)

Xerente: aikte pré (baby)

Xakriabá: <aïcuté> H (child)

Akroá: $\quad<$ aikutä $>$ (child)

In northern Jê the form -kra is attested in Xikrin. The Xakriabá and Akroá forms seem to contain the 1 sg possessive prefix $<\mathbf{i n}->$.

DAUGHTER, GirL:

Proto-Central Jê: *-bakono

Xavante: -ba?õno

Xerente: - -bakno

Akroá: $\quad<$ dewakonó>

DEER:

Proto-Central Jê: $\quad$ *po

Xavante: pone, poze

Xerente: pone

Xakriabá: $\quad<$ pó $>(\mathrm{H})$

Panará: $\quad$ ĩpo $\quad$ (Rodrigues \& Dourado 2012)

The Xakriabá form is probably the general root for 'deer'. Saint-Hilaire (1848: 289) describes the vowel as strongly open ("très ouvert") which approximates it to [0]. According to Maybury-Lewis (1967: 38) the common Xavante root for deer is [po], the occurrence of this root with - $[\mathbf{n e}]$ and - $[\mathbf{z \varepsilon}]$ indicating particular species of deer. Nimuendaju (1929: 128) gives two forms for different species of deer in Xerente: <po $>$ 'Veado campeiro' and < ponë> 'Veado matteiro'. 
FiSH:

Proto-Central Jê: *tebe

Xavante: tebe

Xerente: tbe

Xakriabá: $\quad<$ tupe $>(\mathrm{H})$

Xikrín: $\quad$ tep $\quad$ (Cabral \& Costa 2004)

Panará: $\quad$ tepi $\quad$ (Rodrigues \& Dourado 2012)

DoG:

Proto-Central Jê: *wapsã

Xavante: wapsã

Xerente: wapsã

Xakriabá: $\quad<$ goabsang $>($ E)

ChICKEN, HeN:

Proto-Central Jê: *sika

Xavante: si?a

Xerente: $\quad$ sika

Xakriabá: $\quad<$ schiká $>(\mathrm{E})$

The Xakriabá form might indicate the innovation of a palatalization rule, $\mathbf{s} \rightarrow \mathbf{J} /{ }_{-} \mathbf{i}$, in this language (assuming $<\mathbf{s c h}>=[\boldsymbol{f}]$ ). However, there is no complementary distribution between $<\mathbf{s}>$ and $<\mathbf{s c h}>$ in the Xakriabá data that could be seen as evidence for this claim: $<\mathbf{s}>$ occurs before $<\mathbf{i}>$ and $<\mathbf{s c h}>$ occurs before $<\mathbf{a}>$, a vowel that, under standard assumptions, does not trigger palatalization. This could indicate the presence of an opposition between alveolar and palatal fricatives in Xakriabá. It is hard to probe into the existence of this distinction, however, since arguing for it would imply a burden of proof that in all likelihood cannot be met with the available data. ${ }^{22}$

The form < sica $>$ is given by Nordenskiöld (1922: 32) to Akroá. Though he cites Martius as the original source for this form, we were not able to find any such entry in the vocabulary of Martius (1867).

Modern sources on Xavante, such as Hall et al. (1987) give /si?a/ as meaning both 'hen' and 'cock'. In Martius (1867), however, a separate form for 'cock' ('gallus') is given: $<$ roaero $>$ and a form $<$ teorá $>$ for 'cock' in Xakriabá. Nordenskiöld (1922: 30) notes that "We find the names schakika, sika, chika etc., among several Gês tribes from the Camacan on the Brazilian coast to about the Rio Tocantins. They evidently indicate a route by which the fowls were conveyed from the coast far inland in E. Brazil".

TAPIR:

$\begin{array}{ll}\text { Proto-Central Jê: } & \text { *kədə } \\ \text { Xavante: } & \text { uhədə } \\ \text { Xerente: } & \text { kdə } \\ \text { Xakriabá: } & <\text { cutó> }>(E) \\ \text { Proto-Southern Jê: } & *\{\mathbf{k}\} \text { ojor }\end{array}$

(Jolkesky 2010)

${ }^{22} \mathrm{~A}$ similar observation applies to the two liquids, $<\mathrm{r}>$ and $<\mathrm{l}>$, that occur in the Akroá data. 
On the Xakriabá word, Saint-Hilaire (1848: 289) notes that the final vowel is "très sourd", making it likely that its quality was close to the centralized timbre found in Xavante and Xerente.

House: ${ }^{23}$

Proto-Central Jê: *kri

Xavante: $\quad$ ?ri

Xerente: $\quad$ kri

Akroá: $\quad<$ kli $>$

Xakriabá: $\quad<$ gri $>(\mathrm{E})$

Xikrín: $\quad$ kikrE (Cabral \& Costa 2004)

Kyikatejê: ajkre (Damulakis 2010)

ARrow:

Proto-Central Jê: *ti

Xavante: $\quad$ ti

Xerente: ti

Akroá: $\quad<$ tikkíte $>$

Xakriabá: $\quad<$ etiké $>$ (E)

HAMMOCK; LINE, THREAD; COTTON:

HАMмоск:

Xavante: Pabazipara

Xerente: badikre

LINE, THREAD:

Xavante: Pabazire

Xerente: kbazire

Cotton:

Proto-Central Jê: *kabazi

Xavante: Pabazi

Xerente: kbazi

Akroá: $\quad$ gebatsi>

These forms are discussed together since they are clearly related and important generalizations can be attained regarding the history of Central Jê groups by treating them in a unified manner. As early as in 1920, Nordenskiöld remarked that "the distribution of the cotton hammock in South America cannot be properly understood except in connection with the general history of the cultivation of cotton" (Nordenskiöld 1920: 14).

The Xerente forms for 'line, thread' and for 'cotton' show that the Xavante form has a phonological glottal stop (that is, $\mathbf{?}<* \mathbf{k}$ ). Ehrenreich 1895 gives a Xavante form for cotton that still preserves the velar stop: $<$ kabadži $>$.

${ }^{23}$ In Martius (1867) the Akroa form is given in the entry for 'domus', while that of Xakriabá is given under 'tugurium'. 
Lowie (1946: 487) describes the use of cotton lines among the Xerente as well as among northern groups such as the Apinajé. He mentions, however, that the Timbira groups do not manufacture cotton hammocks and that the only case of regular use of hammocks among Timbira groups is clearly a case of Guajajara (Tupi-Guarani) influence (pg. 484). Lowie (1946: 484) states that hammocks are made out of buriti leaves among the Timbira and the Xerente when these build temporary shelters, usually during hunting. On the use of cotton hammocks, Nordenskiöld (1920: 13) shows that while it is true that along the Amazon river there is a prevalence of groups that use hammocks made of palmfiber, elsewhere most groups use cotton-woven hammocks and that this is probably an innovation spread by Tupi-Guaraní and Carib groups. He also notes that "On the coast of Brazil, the more civilized Tupi has cotton hammocks, while the less civilized tribes use palm-fiber" (pg. 13). ${ }^{24}$

MANIOC:

$\begin{array}{ll}\text { Proto-Central Jê: } & \text { *kupa } \\ \text { Xavante: } & \text { 'Pupa } \\ \text { Xerente: } & \text { ku'pa } \\ \text { Akroá: } & \text { <cuipá> } \\ & \\ \text { Proto-Jê: } & \text { *kwir } \\ \text { Proto-Southern Jê: } & \text { *kube\{d\} }\end{array}$

(Davis 1966) $^{25}$

(Jolkesky 2010)

ToвACсо:

Xerente: warĩ

MAIZE:

Akroá: <uari>

$\begin{array}{ll}\text { Proto-Central Jê: } & \text { *dõzə [nõzə] } \\ \text { Xavante: } & \text { dõzə } \\ \text { Xerente: } & \text { dõzə } \\ \text { Akroá: } & <\text { notschiö> }\end{array}$

See the form for FIRE below for the discussion of another instance of Akwen $\mathbf{z}$ corresponding to $<\mathbf{t s c h}>$. Note that in the reconstructed form for MAIZE we postulate the same allophonic process seen in Xavante and Xerente whereby voiced oral stops surface as nasal stops in the context of a following nasal vowel.

TREE:

$\begin{array}{cll}\text { Proto-Central Jê: } & \text { *wede } & \\ \text { Xavante: } & \text { 'wede } & \\ \text { Xerente: } & \text { w'de } & \\ \text { Xakriabá: } & <\text { odé, oté> (E) } & \\ \text { Akroá: } & <\text { wetecklü> } & \text { 'smoking-pipe' }\end{array}$

\footnotetext{
${ }^{24}$ There may be evidence that the Xerente did use palm-fiber hammocks after all. Gardner (1846) registered the name for the fruit of a palm tree given by the Akroá: shòdò (pg. 317). Some older sources on the Xerente, such as Socrates (1892) give socozé for 'hammock', arguably containing the root for the palm tree, so-.

${ }^{25}$ Davis (1966) employs [y] to represent the high central vowel. We opted here for the IPA symbol [i]].It is also important to note that Davis (1966) does not include a Xavante witness in his etymology for 'manioc'. As a matter of fact, only forms attested in Northern Jê languages (Canela, Suyá and Apinajé) are considered.
} 
Although Martius (1867) does not indicate it, the form < <dé> comes from Saint-Hilaire (1848), who indicates, in addition, that the final $<$ é $>$ sounds like the closed French vowel [e] ("prononcez l'e comme l'e fermé français"). This observation suggests a clear match with the vowel qualities attested in Xavante and Xerente. The Akroá form means 'smoking-pipe' and seems to include the term $<$ wete $>$ which likely stands for 'wood, tree' (but cf. LEAF below for a slightly different transcription), plus a form $<\mathbf{c k l u ̈}>$ which may be a classifier of sorts, indicating 'round objects' or 'holes' (see the forms for EAR, NOSE and VAGINA; cf. also Siqueira 2009 for krə̃) as a classifier for 'round objects' in Xerente).

LEAF:

\begin{tabular}{|c|c|c|}
\hline Proto-Central Jê: & 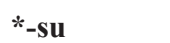 & \\
\hline Xavante: & $-\mathbf{s u}$ & \\
\hline Xerente: & he'su & \\
\hline Xakriabá: & $<$ deçu $>(\mathrm{H})$ & \\
\hline Akroá: & <uöthésu> & \\
\hline Proto-Jê: & ${ }^{*}$ zo, *zoc & (Davis 1966) \\
\hline Panará: & -so & (Dourado 2001: 22) \\
\hline
\end{tabular}

The Xakriabá and Akroá forms seem to contain the root for 'tree' (cf. TREE above).

WOOD, FIREWOOD:

Proto-Central Jê: *mi

Xavante: $\quad$ mi

Xerente: $\quad$ mmi

Akroá: $\quad<\mathbf{m i}>$

Proto-Jê: $\quad$ *pĩ $\quad$ (Davis 1966; under 'tree; firewood')

Proto-Southern Jê: *pĩ(f) ～(Jolkesky 2010)

EARTH:

Proto-Central Jê: *tika

Xavante: ti?a

Xerente: tka

Xakriabá: $\quad<$ tica $>(E)$

Akroá: $\quad<$ tickáiti $>$

Proto-Jê: $\quad$ *pi-ka, *kan $\quad$ (Davis 1966)

The Akroá word seems to include the predicator $<-\mathbf{t i}>$.

Moon:

$\begin{array}{ll}\text { Proto-Central Jê: } & { }^{*} \text { wa } \\ \text { Xerente: } & \text { wa } \\ \text { Xakriabá: } & <\text { oà, ua> } \\ \text { Akroá: } & <\text { uati }>\end{array}$

Once more the Akroá form occurs with the predicator $<-\mathbf{t i}>$. 
WATER:

Proto-Central Jê: *kə

Xavante: $\quad$ Po

Xerente: $\quad$ kə

Xakriabá: $\quad<\mathbf{k u}, \mathbf{k u ̈}>(\mathrm{E})$

Proto-Southern Jê: *goj (Jolkesky 2010)

Proto-Jê: *yo, *noc (Davis 1966)

Panará: $\quad$ ĩko (Rodrigues \& Dourado 2012)

Kyikatejê: ko (Damulakis 2010)

RAIN:

Proto-Central Jê: *tã

Xavante: tã

Xerente: $\quad$ tõ

Akroá: $\quad<$ thaite $>$

Proto-Jê: *na (Davis 1966)

Proto-Southern Jê: *ta (Jolkesky 2010)

Panará: $\quad$ ĩta $\quad$ (Rodrigues \& Dourado 2012)

The Akroá form may include the predicator transcribed as $<$-te $>$.

LAKE:

$\begin{array}{ll}\text { Proto-Central Jê: } & \text { *pu-ku } \\ \text { Xavante: } & \text { pu 'lake with its own water source' } \\ \text { Xerente: } & \text { pku } \\ \text { Akroá: } & <\text { puckúte }>\end{array}$

FIRE:

$\begin{array}{ll}\text { Proto-Central Jê: } & \text { *kuzə } \\ \text { Xavante: } & \text { Pu'zə } \\ \text { Xerente: } & \text { ku'zi } \\ \text { Xakriabá: } & <\text { kutsché> (E) } \\ \text { Akroá: } & <\text { kutschiopdé(i)> }\end{array}$

Proto-Jê: $\quad$ *ku-zi $\quad$ (Davis 1966)

Note that a correspondence between Akwen $\mathbf{z}$ and Xakriabá/Akroá $<\mathbf{t s c h}>$ seems to be recurrent (see also the form for MAIZE). Based on the German orthographic conventions (likely followed by both Eschwege and Martius), $<\mathbf{t s c h}>$ would stand for [t $\int$ ]. Since [d3] does not occur in German, it is not impossible that the actual Xakriabá/Akroá forms had [d3] instead (cf. section 1.1 on Saint-Hilaire's (1848) observations on Eschwege's transcriptions). Note that the affricate $[\mathbf{d z}]$ is one possible realization of the fricative $/ \mathbf{z} /$ in Xavante (cf. Quintino 2012: 134).

${ }^{26}$ Ribeiro (2004: 98) suggests a revised reconstruction for this form as *si. The first syllable, *ku would mean 'wood, trunk'. 
The Akroá form seems to include more than the root for 'fire', though it is hard to say anything more concrete on the final sequence $<$ opdé(i) $>$. It might include the 'predicator' suffix $<\mathbf{d e}>$ seen elsewhere in the Akroá data.

RED:

$\begin{array}{ll}\text { Proto-Central Jê: } & \text { *-pre } \\ \text { Xavante: } & \text {-pre } \\ \text { Xerente: } & \text {-pre } \\ \text { Xakriabá: } & <\text { oipredé> }(\mathrm{H}) \\ \text { Akroá: } & <\text { schikutzabrö> }\end{array}$

Kyikatejê: $\quad$ kapre $\quad$ (Damulakis 2010)

The Xakriabá form is readily analyzable into the 2 sg prefix $<\boldsymbol{0}$ ï- $>$, the root $<$ pre $>$ and the suffix $<$-dé $>$. The symbol ' $E$ ' in the reconstructed form indicates uncertainty concerning this vowel's quality.

The Akroá form is less clear. The sequence $<$ brö $>$ could be identified as the root, a rather close match to the Akwen items, though one would need to account for the sequence $<$ schikutza $>$. Evidence for this analysis comes from the fact that the latter formative occurs in a number of other color terms given in Martius (1867), such as $<$ schikutzacráng $>$ 'blue' (also < schikutzacrang $>$ 'black') and $<$ schicutschawabtöide $>$ 'yellow'. On simple distributional grounds, then, it is plausible to suggest that $<\mathbf{b r o ̈}\rangle$ is a separate formative and likely the Akroá root for 'red'.

\section{BeAutiful:}

Proto-Central Jê: *-pese

Xavante: $\quad$ ropese 'to clean (a patch of land)'

Xerente: psere

Xakriabá: $\quad<$ dapside $>(\mathrm{H})$

Akroá: $\quad<$ aimbösetí>

The morpheme $<\mathbf{d a}->$ 'general human possession' is seen in the Xakriabá form; the 2 sg prefix $<$ ai- $>$ in Akroá and both forms show the 'predicator' or 'stative' $<-\mathbf{d e}>,<-\mathbf{t i ́}>$.

\section{Additional notes on morphology and morpheme structure}

In at least some of the Xakriabá and Akroá words it may be possible to identify one of the exponents of the so-called 'Relational morpheme' (cf. Rodrigues 2000; Cabral \& Costa 2004; Ribeiro 2004 on the relational morpheme in Jê, Macro-Jê and Tupí-Guaraní). Instances of relational morphemes are indicated in bold in the table below:

(12) Akroá and Xakriabá forms likely displaying the relational morpheme:

\begin{tabular}{|c|c|c|}
\hline Akroá & Xakriabá & \\
\hline$<$ ai-m-buttú-de $>$ & & 'neck' \\
\hline$<$ ai-m-böse-tí $>$ & & 'good' \\
\hline$<$ a-ss-ubckrá>27 & da-j-ipcra $>,<$ d'a-sch-ipigrá $>$ & 'hand' \\
\hline
\end{tabular}




$\begin{array}{ccc}\begin{array}{c}<\text { ai-n-thó }> \\ <\text { a-s-pocklü }>\end{array} & \text { 'eye' } \\ <\text { a-ss-ötauá }> & <\text { 'ear' } \\ <\text { a-ss-ockthúdü }> & <\text { da-ï-daua }> & \text { 'mouth' } \\ & <\text { d'a-nh-ocutû }> & \text { 'chest' }\end{array}$

Many of the forms in Akroá and Xakriabá that apparently show relational morphemes behave in a similar way to the pattern described for Xavante. Thus, the occurrence of a voiceless fricative $\langle\mathbf{s}>$ and $<\mathbf{s s}>$ following the 2sg prefix in Akroá, and the presence of nasal $<\mathbf{n h}>$ after the prefix for general human possession in Xakriabá, reflects the same pattern described by Rodrigues (2000) for Xavante.

The hypothesis that these forms show the presence of relational morphemes will not be evaluated in any depth here, but seems to merit more attention and, to our knowledge, has not been raised before in the published literature. We note, however, that the very existence of the relational morphemes qua independent morphemes - as opposed to root-initial consonants that show a morphologically conditioned pattern of alternation - has been questioned recently (cf. e.g. Salanova 2009 for Jê and Meira \& Drude 2013 for Tupi-Guarani). An evaluation of the Akroá and Xakriabá forms will, no doubt, depend on additional clarifications eventually resulting from the debate over the status of such patterns.

An additional feature of both Xakriabá and Akroá forms is the presence of 'echo vowels' assumed to have been inserted in word-final position in Proto-Jê words ending in a consonant (cf. Davis 1966: 16-7; Ribeiro \& van der Voort 2010: 554). As shown in (13), these root-final vowels are found in these languages, being absent from their reconstructed Proto-Jê sources and from Northern Jê. Proto-Jê forms come from Davis (1966). Northern Jê roots come from both Davis (1966) and Alves (2007):

(13) Echo vowels in Akroá and Xakriabá forms:

\begin{tabular}{|c|c|c|c|c|}
\hline Proto-Jê & Xakriabá & Akroá & Northern Jê & \\
\hline$*$ tep & $<$ tupe $>$ & ---------- & tep $p_{\text {Apinajé }}$ & 'fish' \\
\hline$*_{\text {mut }}$ & $<$ d'aputû $>$ & $<$ aimbuttúde $>$ & put Apãniekrá & 'neck' \\
\hline *par & $<$ daprá $>,<$ d'aprá $>$ & ----------- & $\operatorname{par}_{\text {Apãniekrá }}$ & 'foot' \\
\hline$*_{\mathrm{m} \varepsilon \mathrm{c}}$ & $<$ dapside $>$ & <aimbösetí> & $\mathrm{m} \mathrm{c}_{\text {Apinajé }}$ & 'good', 'beautiful' \\
\hline
\end{tabular}

\section{Synthesis, conclusions and open issues}

The goal of the present study was to cast further light on the structure of the Akroá and Xakriabá languages, based on a comparison between their attested forms and their presumed cognates occurring in Xavante and Xerente, their closest relatives. As a consequence of this effort, more information has been gained on the relation between the languages forming the central branch of the Jê linguistic family.

\footnotetext{
${ }^{27}$ The digraph $<\mathbf{s s}>$ stands for voiceless [s] in standard German orthography (cf. also Vasconcelos 2009).
} 
On the one hand, it was shown that both Xakriabá and Akroá share with Xerente the retention of velar stops * $\mathbf{k}$ which were, in turn, changed to $\mathbf{P}$ in Xavante. On the other hand, an apparent innovation - the loss or reduction of some vowels - is shared between Xerente, Akroá and Xakriabá, though this shared innovation is not enough to justify grouping these three languages within central Jê, leaving Xavante as a separate branch.

The overall picture offered here may be seen as supporting the attribution of a 'flat' structure to the central branch of the Jê family (14 below), a view which is at odds with the usual recognition of an 'Akwen subgroup' or 'cluster' including only Xavante and Xerente (see last paragraph of section $\mathbf{3}$ for suggestions on the origin of this pattern of diversification).

\section{(14) The Central Jê Languages:}

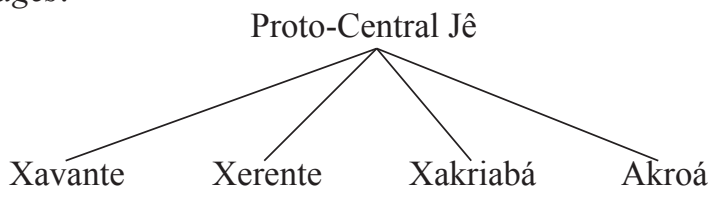

It is true, however, that subgroups are justified by the identification of sets of shared innovations in phonology, morphology and syntax. Since the evidence available on Akroá and Xakriabá is extremely exiguous (one would say non-existent as far as much of morphology and all of syntax are concerned), it could be the case that many shared innovations characterize the so-called Akwen group, but that the data on the other central Jê languages is not good enough to establish this beyond doubt. In short: though the argumentation developed here supports a flat structure for the central Jê subgroup implying thus that no 'Akwen subgroup' exists -, this claim should be understood from the perspective of the virtual absence of potentially disconfirming evidence and should therefore be weighted accordingly.

In addition, a total of 42 central-Jê etymologies were proposed along with analyses of the morphological composition of the forms in the lists of the two fragmentary languages. Some of these claims may be seen as hypotheses open to further scrutiny by interested independent researchers, being ultimately strengthened or rejected to the extent allowed by the limited data available on Akroá and Xakriabá.

It is important to stress the fact that the present study is actually the first one to deal exclusively with the central branch of the Jê family from a historical comparative perspective. Though this subgroup is relatively shallow in the sense that its member languages do not seem strongly differentiated, there is no published study demonstrating the linguistic bases for the recognition of the central Jê subgroup as a distinct entity from the northern and southern branches of the family. A careful comparison of the central Jê languages with its northern and southern relatives with the goal of finding shared innovations supporting each of the postulated subgroups makes a natural next step for historical and comparative investigation. On a more descriptive side, our understanding of the sound structure of Xerente and Xavante could be greatly improved by careful phonetic investigation, especially as it regards difficult contrasts such as $/ \mathrm{\partial} / \mathrm{-} / \mathrm{i} /$, the occurrence of long (geminate) segments and the phonology of nasalization. 


\section{References}

ALVES, Flávia de Castro (2007). Sistema fonológico do Timbira Apãniekrá. In Aryon Dall'Igna Rodrigues; Ana Suelly Cabral (eds.). Linguas e Culturas Macro-Jê, pp. 45-55. Brasília: Editora Universidade de Brasília.

APOLINÁRIO, Juciene Ricarte (2005). Os Akroá e outros povos indígenas na fronteira do sertão. Doctoral Dissertation. Recife: Universidade Federal de Pernambuco.

CABRAL, Ana Suelly; COSTA, Lucivaldo da (2004). Xikrín e línguas tupí-guaraní: Marcas relacionais. LIAMES 4: 7-19.

COIMBRA Jr., Carlos E. A.; FLOWERS, Nancy M.; SALZANO, Francisco M.; SANTOS, Ricardo B. (2002). The Xavánte in transition: Health, ecology and bioanthropology in Central Brazil. Ann Arbor: The University of Michigan Press.

DAMULAKIS, Gean N. (2010). Fonologias de línguas Macro-Jê: Uma análise comparativa via teoria da otimalidade. Doctoral Dissertation in Linguistica. Rio de Janeiro: Universidade Federal do Rio de Janeiro.

DAVIS, Irvine (1966). Comparative jê phonology. Estudos Linguísticos: Revista Brasileira de Linguística Teórica e Aplicada 1(2): 10-24.

EHRENREICH, Paul (1895). Materialen zur Sprachenkunde Brasiliens III: Die Sprache der Akuä oder Chavantes und Cherentes (Goyaz)'. Zeitschrift für Ethnologie 27: 149-162.

ESCHWEGE, L. Von (1830). Brasilien die neue Welt. Braunschweig.

GARDNER, George (1846). Travels in the interior of Brazil. London: Reeve Brothers.

HALL, Joan; McLEOD, Ruth Alice; MITCHELL, Valerie (1987). Pequeno dicionário Xavante-Português, Português-Xavante. Brasília, DF.: Summer Institute of Linguistics.

JOLKESKY, Marcelo Pinho De Valhery (2010). Reconstrução fonológica e lexical do Proto-Jê Meridional. M. A. Thesis in Linguistics. Campinas: IEL-UNICAMP.

KRIEGER, Wanda Braidotti; KRIEGER, Guenter Carlos (1994). Dicionário escolar Xerente-Português, Português-Xerente. Rio de Janeiro: Junta de Missões Nacionais da Convenção Batista.

LOWIE, Robert H. (1946). The Northwestern and Central Ge. In Julian H. Steward (ed.). The Handbook of South American Indians, vol. 1: 477-518. The Marginal Tribes. New York: Smithsonian Institution. Bureau of American Ethnology, Bulletin 143.

MARTIUS, Karl Friedrich Phil von (1867). Beiträge zur Ethnographie und Sprachenkunde Amerika's zumal Brasiliens, II. Glossaria Linguarum Brasiliensium. Leipzig: Friedrich Fleischer.

MATTOS, Rinaldo de (1973). Fonêmica Xerente. Série Linguística 1: 79-100. Brasília, DF.: Summer Institute of Linguistics.

MAYBURY-LEWIS, David (1965). Some crucial distinctions in Central Brazilian Ethnology. Anthropos 60: 340-58.

MAYBURY-LEWIS, David (1967). Akwe-Shavante society. Oxford: Clarendon Press.

McLEOD, Ruth; MITCHELL, Valerie (1977). Aspectos da lingua Xavante. Brasília, DF.: Summer Institute of Linguistics. 
MEIRA, Sérgio; DRUDE, Sebastian (2013). Sobre a origem histórica dos prefixos relacionais das línguas TupíGuaraní. Cadernos de Etnolinguística, vol. 5, n. 1. http://www.etnolinguistica.org/issue.vol5n1

NIMUENDAJÚ, Curt (n.d.). Curta lista vocabular em Sakriabá e Serente. Manuscript. Centro de Documentação de Línguas Indígenas (CELIN), Museu Nacional, Universidade Federal do Rio de Janeiro (UFRJ).

NIMUENDAJÚ, Curt (1929). Lingua Serénte. Journal de la Société des Américanistes 21(1): 127-130.

NIMUENDAJÚ, Curt; Robert LOWIE (1937). The dual organizations of the Ramko'krameka (Canella) of Northern Brazil. American Anthropologist 39 (4): 565-582.

NORDENSKIÖLD, Erland (1920). The Changes in the material culture of two indian tribes under the influence of new surroundings. Comparative Ethnographical Studies 2. Göteborg: Elanders Boktryckeri Aktiebolag.

NORDENSKIÖLD, Erland (1922). Deductions suggested by the geographical distribution of some postcolumbian words used by the Indians of South America. Comparative Ethnographical Studies 5. Göteborg: Elanders Boktryckeri Aktiebolag.

POHL, Johann Emanuel (1832). Reise im Innern von Brasilien, vol. 1. Wien: Strauss Witwe

QUINTINO, Wellington Pedrosa (2000). Aspectos da fonologia Xavante. M.A. Thesis in Linguistics. Campinas: IEL-UNICAMP.

QUINTINO, Wellington Pedrosa (2012). Aspectos da fonologia Xavante e questões relacionadas: Rinoglotofilia e nasalidade. Doctoral Dissertation in Linguistics. Rio de Janeiro: UFRJ.

RAMIREZ, Henri (2001). Linguas Arawak da Amazônia Setentrional: Comparação e descrição. Manaus: Editora da Universidade do Amazonas.

RIBEIRO, Eduardo Rivail (2004). Prefixos relacionais em Jê e Karajá: Um estudo histórico-comparativo. LIAMES 4: 91-101.

RIBEIRO, Eduardo Rivail (2009). Tapuya connections: Language contact in Eastern Brazil. LIAMES 9: 61-76.

RIBEIRO, Eduardo Rivail (2012). George Gardener entre os índios do sertão. Blog da Biblioteca Digital Curt Nimuendajú. Disponível em: http//:www.etnolinguistica.org/doc:17.

RIBEIRO, Eduardo Rivail; VOORT, Hein van der (2010). Nimuendajú was right: The inclusion of the Jabutí family in the macro-jê stock. International Journal of American Linguistics 76(4): 517-570.

RODRIGUES, Aryon Dall'Igna (1999). Macro-Jê. In R. M.W. Dixon; Alexandra Y. Aikhenvald (eds.). The Amazonian Languages, pp. 165-206. Cambridge: Cambridge University Press.

RODRIGUES, Aryon Dall'Igna (2000). Flexão relacional no tronco macro-jê. Boletim da Associação Brasileira de Linguística 25: 219-231.

RODRIGUES, Aryon Dall'Igna (2002). Para o estudo histórico-comparativo das línguas jê. In Ludoviko dos Santos; Ismael Pontes (eds.). Línguas jê: Estudos vários, pp. 1-14. Londrina: Universidade Estadual de Londrina.

RODRIGUES, Aryon Dall'Igna (2004). Sobre a possível origem da diferença fonética entre a fala masculina e a feminina em Karajá. LIAMES 4: 115-121.

RODRIGUES, Aryon Dall'Igna; DOURADO, Luciana (2012). Panará: Identificação linguística dos KrenAkarore com os Cayapó do Sul. Revista Brasileira de Linguística Antropológica 4(2): 255-256. [First published in 1993]. 
DE CARVALHO \& DAMULAKIS - The Structure of Akró́ And Xakriabá ...

SAINT-HILAIRE, Auguste de (1848). Voyage aux sources du Rio de S. Francisco et dans la province de Goyaz, t. 2. Paris: Arthur Bertrand.

SALANOVA, Andrés Pablo (2009). Não existem prefixos relacionais em línguas jê. In Silvia Lucia Bingonjal Braggio; Sinval Martins de Sousa Filho (eds.). Linguas e culturas macro-jê, pp. 259-271. Goiânia: Editora Vieira

SANTOS, Julina Pereira (2008). Marcas pessoais, concordância de número e alinhamento em Xavánte. M.A. Thesis in Linguistics: Brasília, DF.: Universidade de Brasília.

SCHMIDT, Wilhem (1926). Die Sprachfamilien und Sprachkreisen der Erde. Heidelberg: C. Winter.

SIQUEIRA, Kenia Mara de Freitas (2009). Nomes de partes em função classificadora: Âmbito de análise do sistema de classificação nominal Akwẽ-Xerente. Via Litterae 1(1): 61-79. www.unucseh.ueg.br/vialitterae

SOUSA FILHO, Sinval Martins de (2005). Categorias morfossintáticas e semânticas do nome Xerente: Número, gênero e grau. Anais do IV Congresso Internacional da ABRALIN: 671-679.

SOUSA FILHO, Sinval Martins de (2011). Padrões de alinhamento morfossintático em Akwen-Xerente (Jê). LIAMES 11: 115-28.

SOUZA, Shelton Lima de (2008). Descrição fonético-fonológica da língua Akwen-Xerente. M.A. Thesis in Linguistics: Brasília, DF.: Universidade de Brasília.

STEINEN, Karl von den (1942 [1886]). O Brasil Central. Expedição em 1884 para a exploração do Rio Xingu. São Paulo: Companhia Editora Nacional.

VASCONCELOS, Eduardo (2009). Sobre as listas de palavras Cayapó do Sul de São José de Mossâmedes. Sinteses: 405-423.

Recebido: 1/5/2014

Versão revista e corrigida: 14/9/2014

Aceito: 5/1/2015 